\title{
219 接触予測制御による研削砥石の位置決め
}

\author{
Positioning of grinding wheel by contact-prediction control \\ ○正 由井明紀 (防衛大)，元谷征樹 (防衛大) \\ 北嶋孝之 (防衛大)，正. 奥山繁樹(防衛大)
}

Akinori Yui, Seiki Mototani, Takayuki Kitajima and Shigeki Okuyama

The National Defense Academy, 1-10-20, Hashirimizu, Yokosuka-city, Kanagawa

\begin{abstract}
Prediction of contact between a grinding wheel and a workpiece is being required from production engineers. A prediction system of grinding-wheel contact was, therefore, developed employing the defused-laser detection from the trailing flow of grinding fluid. In this paper, the prediction system has been applied to grinding-wheel positioning. Trigger signal from the prediction system for stopping the wheel feed is sent to NC system when the diffused-laser intensity exceeds a certain level. Unevenness of the detected laser intensity results in the positioning error, which increases with the wheel-approach speed. Therefore, the trigger level is increased discretely with decrease of the wheel-approach speed. The wheel-positioning accuracy of the proposed system is 10 to $20 \mu \mathrm{m}$.
\end{abstract}

Key words: Grinding Wheel, Wheel Positioning, Positioning Accuracy, Wheel Contact Prediction, Wheel Approach Speed

\section{1. 緒 言}

平面研削加工において，研削砥石をミクロンオーダで加工物に近 づけることは，熟練技能者にとっても容易ではない，特に，最近の 全閉力バ一付き研削盤や大型の平面研削盤においては，さらに困難 を伴う．図1に，作業者 5 名（熟練者と初心者を含む）が平面研削 盤による研削砥石の位置決めを手動にて行った際の，研削砥石と加 工物の距離 $\Delta Y$ を示寸，回転中の外径 $\phi 350$ の研削砥石を 15 秒以内 でどこまで加工物に近づけられるかを，6回づつ㬰施して $\Delta Y$ を測定

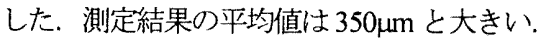

研削砥石は $10 \mu \mathrm{m}$ でも切り込み過ぎると,加工物に損傷を与える. このため, 加工物に接触する前に研削砥石の位置情報を知る必要が ある. そこで，研削砥石が加工物に接近した際の物理現象の変化を 捕らえ，研削砥石の加工物に対寸る接触予知の研究を行ってきた. 例えば，回転中の研削砥石が加工物に接近すると，研削液が白濁す る.これは，研削砥石と加工物の間を通過する研削液に，研削砥石 と連れ回った大気中の空気が混入して気泡が発生するためである. 研削液にレーザを照射すると，透明な場合と白濁した場合とでは反 射率が変化するので， $\Delta Y$ を予知することができる ${ }^{1)}$ ．また，注水， ズルに水中マイクを挿入し，研削液を通じて測定できる特定周波数 の音響解析を行うことにより， $\Delta Y$ を予知することも可能である ${ }^{2)}$.

本報では，このような予知結果に基づいて，平面研削盤の研削砈 石を位置決め制御する方法について検討寸る。 寸なわち，高速接近 する研削砥石が加工物之接触する直前に停止するよう，自動位置決 めを試みる．目標とする位置決め精度は作業者による平均值より 1 桁小さい $35 \mu \mathrm{m}$ 以下とし，位置決め時間の短縮方法についても検討 する。

\section{2. 測定装置および測定方法}

研削砥石の接触予知には，キーエンス製半導体レーザLV-H42（ $\lambda$ $=650 \mathrm{~nm}$, 出力 $3 \mathrm{~mW}$ ) を使用した. 研削盤は, 上下最大送り速度 $1000 \mathrm{~mm} / \mathrm{min}$ ，最小指令単位 $0.1 \mu \mathrm{m}$ の平面研削盤（岡本工作機械製 PSG-63EX）を用いた. 加工物を研削した後，3回スパークアウトし た際の研削盤Y座標の表示值を $0 \mathrm{~mm}$ にリセットし，自動位置決め 時における表示值より $\Delta Y$ を求めた。

図 2 に示すように，レーザセンサはナーブル上に設置し，砥石と 加工物の間隙を通過した直後の研削液にレーザ光を照射して，乱反

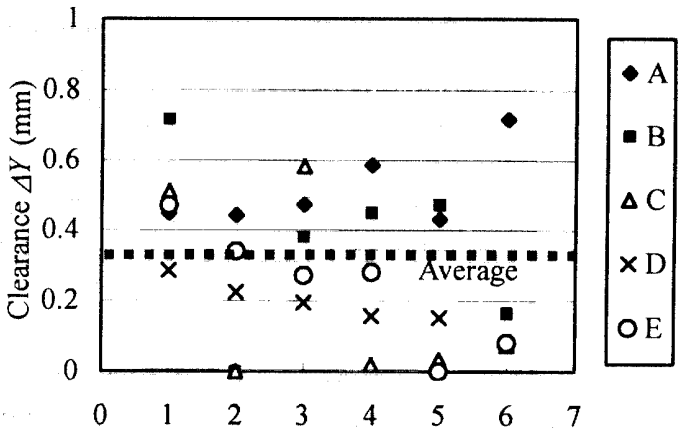

Fig. 1 Accuracy of manual wheel positioning

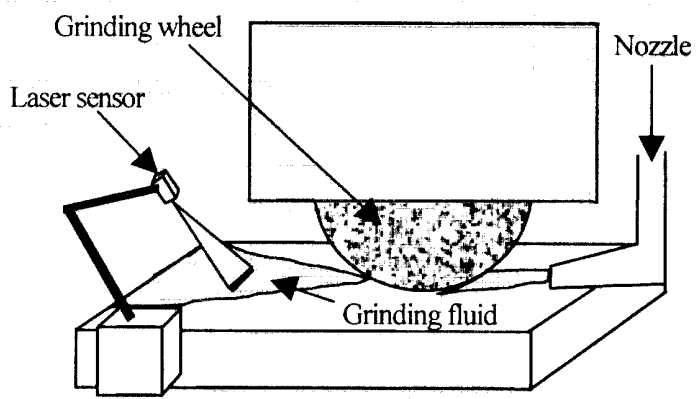

Fig.2 Principle of prediction of grinding wheel contact

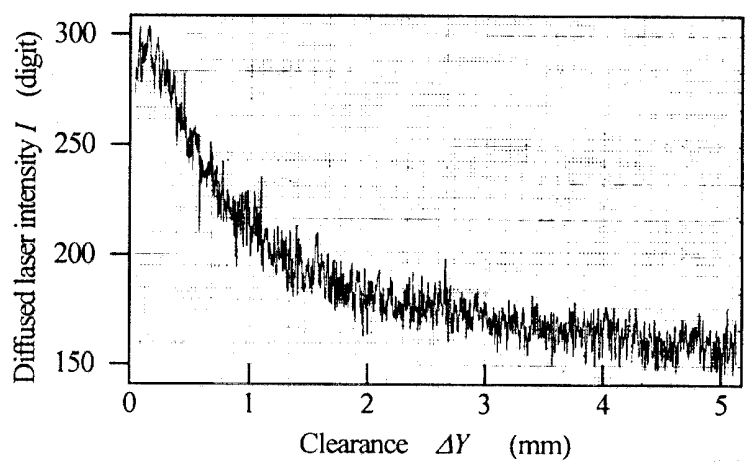

Fig. 3 Change of detected laser intensity, $I$, with $\Delta Y$ (Approach speed: $10 \mathrm{~mm} / \mathrm{min}$ )

日本機械学会〔No.02-25]第 4 回生産加工・工作機械部門講演会講演論文集〔'02-11-21,22,犬山] 
射光の強度 $I$ を測定した，基本的な実験条件を表 1 に示す.

\section{3. 接触予知信号の処理方法}

研削砥石と加工物の間隙を通過した研削液にレーザ光を照射し， $\Delta Y$ を変化させて $I$ を測定した際の生波形を図 3 に示す. 研削液の流 れは一定でなく，Iの測定值にはばらつきがある．図 4 に，研削砥 石接近速度 $V y$ と位置決め誤差の平均值との関係を示す，Vyが小さ いほど，誤差が減少する. 例えば, トリガレベル $I t$ 一定の条件で, Vy が $100 \mathrm{~mm} / \mathrm{min}$ の場合, $0.3 \sim 0.4 \mathrm{~mm}$ の位置決め誤差があるが， $5 \mathrm{~mm} / \mathrm{min}$ ではその誤差が $0.02 \mathrm{~mm}$ 程度になる.

研削砥石を高速で加工物に接近させた場合，停止すべき位置を検 知してから，実際に研削砥石が停止するまでの電気的・機械的遅れ に起因するタイムラグとこれに伴うオーバーシュートは無視できな い．またＩの時間的なばらつきはVと無関係であるが，研削砥石 の停止位置のばらつきはりに比例して大きくなる.

研削砥石の停止信号を研削盤制御装置に出力するためのトリガレ ベル I $t$ は, 自動位置決めを行う前に $I$ と $\Delta Y$ の関係を求め, 決定する 必要がある.

\section{4. 測定結果}

VyとIt を変化させて自動位置決めを行った際の $\Delta Y$ の測定結果を 図 5 に示す． $V y$ が速い場合には，停止信号出力後の時間遅れに起因 するオーバーシュート量が大きくなる．このため，研削砥石を加工 物に最接近させることができるI 場合は接近時間を短くできるが，停止位置のばらつきは大きい，逆 に，Vyを遅くすると停止位置は $30 \mu \mathrm{m}$ 程度に設定できるが，位置決 めに長時間を要する.

そこで, 研削砥石の接近に伴い設定した $I t$ を超えると自動的に V を低速に切り換え, さらに It を段階的に高くして $\Delta Y$ の值をできる だけ小さくする自動位置決め制御を行うことにする. 図6にりを段 階的に変えた際の, $\Delta Y$ と It の関係を示す. 例えば, 研削砥石は $100 \mathrm{~mm} / \mathrm{min}$ で $I t=150$ digit に達寸るまで接近し，VyとIt を順次切り 換えて $5 \mathrm{~mm} / \mathrm{min}, I t=350$ digit に設定することにより $10 \sim 30 \mu \mathrm{m}$ の範 囲で位置決めが可能になる.

なお，本システムでは加工物から約 $5 \mathrm{~mm}$ の位置から初期接近速 度 $100 \mathrm{~mm} / \mathrm{min}$ にて, 研削砥石が自動停止するまでに要する時間は 3.2 3.7 秒であり, 熟練技能者よりも短時間で高精度な位置決めが 可能となった.

\section{5 結 言}

研削砥石の接触予知信号を平面研削盤の制御装置に取り込むこと により，研削砥石の自動位置決めを行い，以下の結論を得た。

1) 研削夜に照射したレーザ散乱光の強度 $I$ や注水ノズルに仕込ん だ水中マイクからの信号出力を測定することにより, 研削砥石と 加工物の距離 $\Delta Y$ に応じた信号出力を得ることができた.

2) 研削砥石接近速度 $V y$ が高い場合は，位置決め誤差が大きくなる.

3）Vyに応じて段階的にトリガレベルを高く設定することにより, $\Delta Y$ 小さくすることができる.

4) 約 $5 \mathrm{~mm}$ 離九た位置より 3〜4 秒の短時間で $\Delta Y=10 \sim 30 \mu \mathrm{m}$ の高 精度な研削砥石の位置決めに成功した。

謝 辞 本研究にご協力いただいた(株)岡本工作機械製作所に心か ら感謝致します.

\section{[参考文献]}

1) 元谷,由井,奥山,北嶋：レーザ散乱光による研削砥石の接触予測

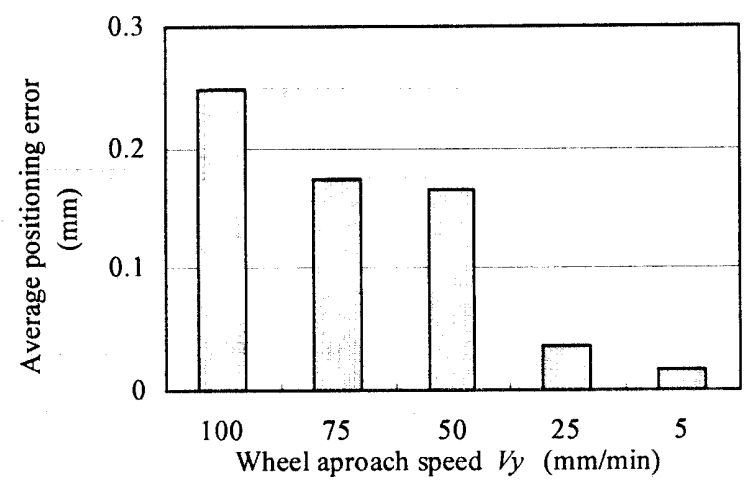

Fig.4 Effects of wheel approach speed on positioning error

Table 1 Experimental conditions

\begin{tabular}{|l|l|}
\hline Grinding fluid & TypeW2-1 \\
\hline Grinding fluid flow rate & $10 \mathrm{~L} / \mathrm{min}$ \\
\hline Laser beam incident angle & $30^{\circ}$ \\
\hline Laser beam irradiation position & $\begin{array}{l}120 \mathrm{~mm} \text { left from the } \\
\text { contact point }\end{array}$ \\
\hline $\begin{array}{l}\text { Distance of grinding wheel and } \\
\text { workpiece }\end{array}$ & $0-5 \mathrm{~mm}$ \\
\hline Grinding wheel & WA60H8V $\phi 350 \times 38$ \\
\hline Peripheral speed of grinding wheel & $30 \mathrm{~m} / \mathrm{s}$ \\
\hline
\end{tabular}

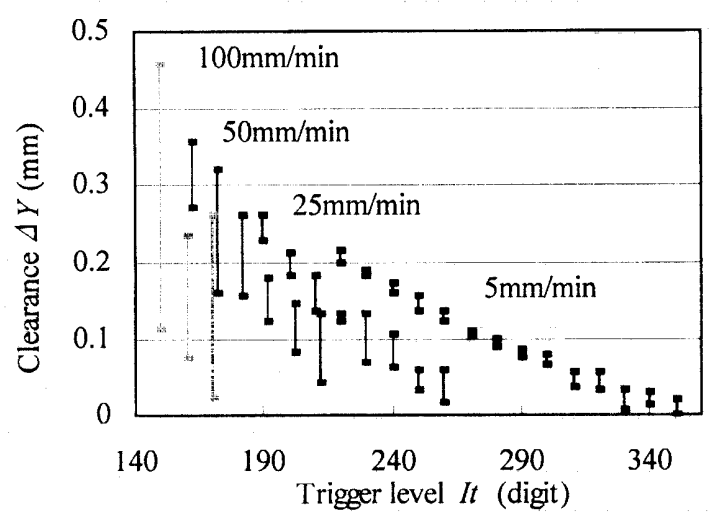

Fig. 5 Effects of wheel approach speed, $L y$,on the distribution of automatically positioned clearance, $\Delta Y$

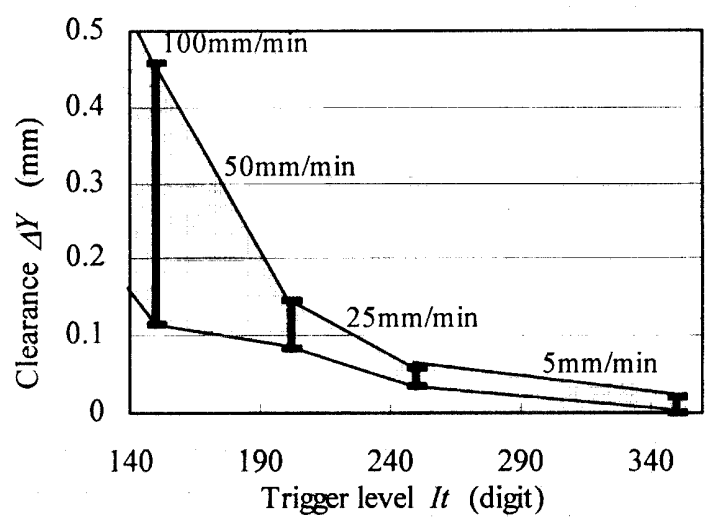

Fig.6 Example of automatic wheel positioning using multi-trigger-level setting

に関寸る研究第 3 回生産加工·工作機械部門講演会講演論文 集,(2001),pl49.

2) 元谷,奥山,由井,北嶋 : 音響解析による研削砥石の接触予知, 砥粒 加工学会学術講演会講演論文集,(2002),p305. 